\title{
Human Leukocyte Antigen DRB1 Alleles Predict Risk and Disease Progression of Immunoglobulin A Nephropathy in Han Chinese
}

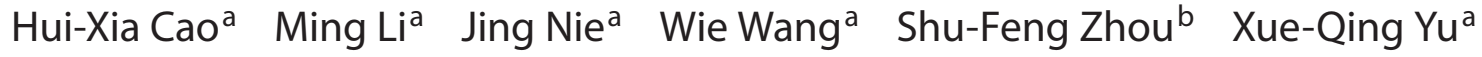 \\ ${ }^{a}$ Department of Nephropathy, The First Affiliated Hospital, Sun Yat-sen University, Guangzhou, China; \\ ${ }^{b}$ Division of Chinese Medicine, School of Health Sciences, WHO Collaborating Center for Traditional Medicine, \\ RMIT University, Melbourne, Vic., Australia
}

\section{Key Words}

HLA-DRB1 • Human leukocyte antigen class II

polymorphism $\cdot$ Immunoglobulin A nephropathy $\cdot$ Allele

\section{Abstract}

The role of human leukocyte antigen (HLA) class II polymorphisms in the pathogenesis and progression of primary immunoglobulin A nephropathy (plgAN) is unclear. This study aimed to explore the relationship of HLA-DRB1 alleles with the susceptibility and disease progression of plgAN in Han Chinese. A PCR-based genotyping technique was used to detect HLA-DRB1 alleles in 139 patients with plgAN and 143 healthy subjects. A total of 37 HLA-DRB1 alleles were detected, of which 30 were found in plgAN patients and 29 in healthy subjects. In plgAN patients, the frequencies of HLA$D R B 1^{*} 140501$ (belonging to $D R^{*} 14$ ) were significantly increased, while the frequencies of HLA-DRB1*070101 (belonging to $D R^{*} 7$ ) were significantly reduced compared with the healthy individuals. Further stratification analysis revealed that the frequencies of $H L A-D R B 1^{*} 030101$ in plgAN patients with normal renal function were significantly higher than those in patients with renal dysfunction. These findings suggest that HLA-DRB1 polymorphisms are related to the occurrence and disease progression of plgAN patients in $\mathrm{Han} \mathrm{Chi}-$ nese, with $H L A-D R B 1^{*} 140501$ being a susceptible allele and

\section{KARGER}

Fax +41613061234

E-Mail karger@karger.ch

www.karger.com
(C) 2008 S. Karger AG, Basel

0250-8095/08/0284-0684\$24.50/0

Accessible online at:

www.karger.com/ajn
HLA-DRB1*070101 a resistant allele. HLA-DRB1*030101 may serve as a predictor of disease progression and renal damage of plgAN in Han Chinese. Further studies are warranted to explore the immunological mechanisms for the genotype-disease phenotype relationship.

Copyright $\odot 2008$ S. Karger AG, Basel

\section{Introduction}

Primary immunoglobulin A nephropathy (pIgAN, also known as Berger's disease) is one of the most common clinical manifestations of primary glomerulonephritis in patients worldwide [1]. Despite extensive research of many years, the molecular mechanisms underlying the pathogenesis of pIgAN remain unclear. Accumulating evidence indicates that genetic factors may play an important role in the development and progression of pIgAN, as demonstrated by a wide ethnic variation in prevalence, familial aggregation, clustering in isolated populations and animal models of hereditary pIgAN [2-5]. In particular, an abnormality of IgA-mediated immune response may play a central role, which is influenced by genetic factors [4].

The human leukocyte antigen (HLA) molecules, which have been mapped on the short arm of chromo-

\footnotetext{
Prof. Xue-Qing Yu, MD, PhD

Department of Nephropathy, The First Affiliated Hospital

Sun Yat-sen University, 58th Zhongshan Road Section II

510080, Guangzhou (China)

Tel. +86208776 6335, Fax +86208776 9673, E-Mail yuxq@mail.sysu.edu.cn
} 
some 6, are important determinants of the IgA-mediated immune response, and HLAs are probably involved in the pathogenesis of pIgAN [6]. HLAs are highly polymorphic transmembrane glycoproteins composed of an $\alpha$ and a $\beta$ subunit and are expressed on the surface of $B$ lymphocytes, macrophages/monocytes and some T lymphocytes [7]. The genes encoding the 3 major expressed class II products are arranged in 3 main subregions: DP, DQ and DR. IgA antibody-mediated response is T cell dependant, and the HLA class II products encoded by the DP, DQ and DR genes are considered to play a crucial role in the presentation of processed antigen to specific $T$ cells [8]. A number of alleles of these genes have been reported. Therefore, the class II allelic polymorphism of the HLA gene may affect the pathogenesis of pIgAN.

An early study by Tolkoff-Rubin et al. [9] demonstrated that pIgAN was in association with allelic variation of $H L A$ genes. In the past decades, there were many clinical studies which provided further evidence indicating a marked association of HLA gene polymorphism and pIgAN [2-5]. Earlier studies have shown that $H L A-D R^{*} 4$ might be associated with pIgAN, especially in Japanese [10-13] and Chinese patients [14]. There is a significant association between $H L A-D Q B 1^{*} 0301$ and IgAN patients with a poor clinical outcome [15]. $D R^{*} 12$ is also associated with PIgAN in Chinese patients [16]. However, studies in Hong Kong [17] and Taiwan [18] did not reveal any association between HLA-DR and pIgAN. It appears that this association exists only in French Caucasians [19], while other studies failed to show a significant association between HLA class II alleles and IgAN [8].

HLA-DRB1, approximately $26-28 \mathrm{kDa}$, is encoded by 6 exons. Exon 1 encodes the leader peptide, exons 2 and 3 encode the 2 extracellular domains, exon 4 encodes the transmembrane domain, and exon 5 encodes the cytoplasmic tail. Within the DR molecule, the $\beta$ chain contains all the polymorphisms specifying the peptide-binding specificities. Hundreds of DRB1 alleles have been identified, and typing of these polymorphisms is routinely conducted for organ (bone marrow and kidney) transplantation. Studies have shown that several alleles at the HLA-DRB1 locus were associated with susceptibility to pIgAN [20]. The incidence of $H L A-D R B 1^{*} 08$ in patients with a family history of IgA nephropathy is higher than sporadic IgA nephropathy [20]. However, data are scant on the relationship of HLA-DRB1 alleles and IgAN in Chinese. In the present study, the association of the HLA$D R B 1$ locus with the predisposition and disease progression in Han Chinese patients with pIgAN was investigated.
Table 1. Characteristics of the study population

\begin{tabular}{lcc}
\hline Variable & IgAN & Healthy subjects \\
\hline $\begin{array}{l}\text { Age, years } \\
\text { Sex }\end{array}$ & $33.1 \pm 12.2$ & $32.6 \pm 13.0$ \\
$\quad$ Male & $62(44.60)$ & $64(44.76)$ \\
$\quad$ Female & $77(55.40)$ & $79(55.24)$ \\
Blood pressure & & \\
$\quad$ Hypertension & $38(28.79)$ & \\
$\quad$ Normal blood pressure & $94(71.21)$ & $143(100.00)$ \\
Content of urine protein & & negative \\
$\quad \geq 1$ g/24 h & $54(40.91)$ & \\
$\quad<1$ g/24 h & $78(59.09)$ & \\
Serum IgA level & & \\
$\quad>3.45 \mathrm{mmol} / 1$ & $35(26.52)$ & \\
$\quad \leq 3.45 \mathrm{mmol} / 1$ & $97(73.48)$ & \\
Gross hematuria & & \\
$\quad$ Yes & $23(17.42)$ & \\
$\quad$ No & $109(82.58)$ & $143(100.00)$ \\
Renal function & & \\
$\quad$ GFR $\leq 60 \mathrm{ml} / \mathrm{min}$ & $33(25.00)$ & \\
$\quad$ GFR $>60 \mathrm{ml} / \mathrm{min}$ & $99(75.00)$ & $143(100.00)$ \\
Haas grade & & \\
I & $23(21.10)$ & \\
II-III & $37(33.94)$ & \\
IV-V & $49(44.95)$ & \\
& &
\end{tabular}

Figures in parentheses are percentages. GFR $=$ Glomerular filtration rate.

\section{Methods}

\section{Patients and Healthy Subjects}

Patients were recruited from the Department of Nephrology, the First Affiliated Hospital of Sun Yat-sen University in Guangzhou, China. A total of 139 patients (age, $33.1 \pm 12.2$ years; sex, 62 males and 77 females) with pIgAN were enrolled in this study. The diagnosis of pIgAN was confirmed by histological and immunological examinations following renal biopsy and met the diagnostic criteria of the World Health Organization [21]. Renal histological lesions of pIgAN patients were evaluated by 2 independent pathologists using the scoring system as described by Haas [22]. All patients underwent detailed medical and biochemical examinations. Patients with systemic diseases such as diabetes, chronic liver disease and systemic lupus erythematosus were excluded. Pregnant women were also excluded.

In addition, 143 healthy gender- and age-matched unrelated subjects with no history of renal disease or hypertension were also recruited on a voluntary basis from Guangdong province (Guangzhou, China). The ethics approval of the study was obtained from the Ethics Committee of the First Affiliated Hospital of Sun Yatsen University (Guangzhou, China), and all participants provided informed consents. 
Table 2. Distribution of $H L A-D R B 1$ allele frequencies in primary IgAN patients and healthy subjects

\begin{tabular}{|c|c|c|c|c|c|c|c|c|c|}
\hline \multirow{2}{*}{$\begin{array}{l}H L A-D R B 1 \\
\text { allele }\end{array}$} & \multicolumn{2}{|c|}{$\operatorname{IgAN}(\mathrm{n}=139 \times 2)$} & \multicolumn{2}{|c|}{ Control $(n=143 \times 2)$} & \multirow{2}{*}{$\chi^{2}$} & \multirow[t]{2}{*}{$\mathrm{p}$} & \multirow[t]{2}{*}{ OR } & \multicolumn{2}{|c|}{$95 \% \mathrm{CI}$} \\
\hline & $\mathrm{n}$ & $\%$ & $\mathrm{n}$ & $\%$ & & & & lower & upper \\
\hline${ }^{*} 010101$ & 2 & 0.72 & 5 & 1.75 & 1.217 & 0.451 & 0.407 & 0.078 & 2.117 \\
\hline *030101 & 24 & 8.63 & 21 & 7.34 & 0.320 & 0.572 & 1.192 & 0.648 & 2.195 \\
\hline${ }^{*} 040101$ & 1 & 0.36 & 1 & 0.35 & ND & 1.000 & 1.029 & 0.064 & 16.531 \\
\hline${ }^{*} 040301$ & 3 & 1.08 & 4 & 1.40 & 0.000 & 1.000 & 0.769 & 0.171 & 3.468 \\
\hline${ }^{*} 0404$ & 1 & 0.36 & 5 & 1.75 & 1.432 & 0.232 & 0.203 & 0.024 & 1.748 \\
\hline${ }^{*} 040501$ & 11 & 3.96 & 5 & 1.75 & 2.495 & 0.114 & 2.315 & 0.794 & 6.752 \\
\hline${ }^{*} 040601$ & 7 & 2.52 & 8 & 2.80 & 0.042 & 0.837 & 0.898 & 0.321 & 2.509 \\
\hline *070101 & 7 & 2.52 & 32 & 11.19 & 16.466 & $0.000^{\mathrm{a}}$ & 0.205 & 0.089 & 0.473 \\
\hline${ }^{*} 080302$ & 11 & 3.96 & 26 & 9.09 & 6.062 & $0.014^{\mathrm{b}}$ & 0.412 & 0.199 & 0.851 \\
\hline${ }^{*} 090102$ & 32 & 11.51 & 37 & 12.94 & 0.267 & 0.605 & 0.875 & 0.528 & 1.450 \\
\hline *100101 & 8 & 2.88 & 3 & 1.05 & 2.465 & 0.116 & 2.795 & 0.734 & 10.646 \\
\hline *110101 & 18 & 6.47 & 13 & 4.55 & 1.010 & 0.315 & 1.454 & 0.698 & 3.027 \\
\hline${ }^{*} 120101$ & 3 & 1.08 & 6 & 2.10 & 0.932 & 0.334 & 0.509 & 0.126 & 2.056 \\
\hline *120201 & 28 & 10.07 & 27 & 9.44 & 0.064 & 0.801 & 1.074 & 0.616 & 1.874 \\
\hline${ }^{*} 130101$ & 2 & 0.72 & 4 & 1.40 & 0.141 & 0.707 & 0.511 & 0.093 & 2.812 \\
\hline${ }^{*} 130201$ & 7 & 2.52 & 10 & 3.50 & 0.462 & 0.497 & 0.713 & 0.267 & 1.900 \\
\hline${ }^{*} 1312$ & 2 & 0.72 & 4 & 1.40 & 0.141 & 0.432 & 0.511 & 0.093 & 2.812 \\
\hline${ }^{*} 140101$ & 29 & 10.43 & 14 & 4.90 & 6.136 & $0.013^{c}$ & 2.263 & 1.169 & 4.381 \\
\hline${ }^{*} 1404$ & 1 & 0.36 & 2 & 0.70 & 0.000 & 1.000 & 0.513 & 0.046 & 5.686 \\
\hline${ }^{*} 140501$ & 25 & 8.99 & 7 & 2.45 & 11.284 & $0.001^{\mathrm{d}}$ & 3.938 & 1.675 & 9.263 \\
\hline${ }^{*} 150101$ & 31 & 11.15 & 25 & 8.74 & 0.915 & 0.399 & 1.310 & 0.752 & 2.282 \\
\hline${ }^{*} 150201$ & 14 & 5.04 & 6 & 2.10 & 3.558 & 0.059 & 2.475 & 0.937 & 6.535 \\
\hline${ }^{*} 160201$ & 4 & 1.44 & 13 & 4.55 & 4.654 & $0.031^{\mathrm{e}}$ & 0.307 & 0.099 & 0.952 \\
\hline Others & 7 & ND & 9 & ND & ND & ND & ND & ND & ND \\
\hline
\end{tabular}

$\mathrm{ND}=$ Not determined. 1.147 .

${ }^{\mathrm{a}} \mathrm{p}^{\prime}<0.0005 \times 37=0.0185 ;{ }^{\mathrm{b}} \mathrm{p}^{\prime}=0.014 \times 37=0.518 ;{ }^{\mathrm{c}} \mathrm{p}^{\prime}=0.013 \times 37=0.481 ;{ }^{\mathrm{d}} \mathrm{p}^{\prime}=0.001 \times 37=0.037 ;{ }^{\mathrm{e}} \mathrm{p}^{\prime}=0.031 \times 37=$

\section{DNA Extraction}

Venous blood samples were obtained from the participants. The genomic DNA was extracted from peripheral blood lymphocytes by using QIAamp DNA Blood Midi Kit (Qiagen, Hilden, Germany), according to the manufacturer protocol.

\section{HLA-DRB1 Genotyping}

The polymorphisms of exon 2 of the HLA-DRB1 gene were determined by PCR-based sequencing technique, as described previously [23]. Some alleles (DRB1*140101 and $D R B 1^{*} 1454$; $D R B 1^{*} 120101, D R B 1^{*} 1206$ and $D R B 1^{*} 1210$; DRB1*040601 and $D R B 1^{*} 040602$ ), which have the same sequences in the second exon region, were unable to be distinguished by the method. We designated them as groups of alleles: DRB1*140101/1454, $D R B 1^{*} 120101 / 1206 / 1210$ and $D R B 1^{*} 040601 / 040602$.

\section{Statistical Analysis}

HLA-DRB1 allele frequencies were calculated by direct counting method. Agreement with Hardy-Weinberg equilibrium was tested for genotype frequencies in the healthy subjects by using PyPop statistical software [24]. The frequency distribution of $H L A-D R B 1$ alleles in patients and healthy subjects was compared by the $\chi^{2}$ test employing a Fisher's exact 2-tailed test where appropriate, and the odds ratios (ORs) and 95\% confidence intervals (CIs) for individuals with a specific genotype were calculated by the methods of Woolf [25]. $\mathrm{p}<0.05$ was considered statistically significant. Corrected $\mathrm{p}$ value $\left(\mathrm{p}^{\prime}\right)$ was obtained by multiplying the $\mathrm{p}$ value by the number of alleles tested for each locus according to Bonferroni's correction method [26]. Demographic and clinical data between groups were compared by Student's test. SPSS version 11.0 for Windows (SPSS, Chicago, Ill., USA) was used for all statistical analyses.

\section{Results and Discussion}

The demographics of the IgAN patients and healthy controls enrolled in this study are shown in table 1 . There were no significant differences between the patients and healthy controls with regard to mean age or gender distribution. One hundred and thirty-two of 139 pIgAN patients had completely recorded clinical data. Meanwhile, 
Table 3. Distribution of $H L A-D R B 1$ alleles in IgAN patients with hypertension or normal blood pressure

\begin{tabular}{|c|c|c|c|c|c|c|c|c|c|}
\hline \multirow[t]{2}{*}{$\begin{array}{l}H L A-D R B 1 \\
\text { allele }\end{array}$} & \multicolumn{2}{|c|}{$\begin{array}{l}\text { Hypertension } \\
(\mathrm{n}=38 \times 2)\end{array}$} & \multicolumn{2}{|c|}{$\begin{array}{l}\text { Normal blood pressure } \\
(\mathrm{n}=94 \times 2)\end{array}$} & \multirow[t]{2}{*}{$\chi^{2}$} & \multirow[t]{2}{*}{$\mathrm{p}$} & \multirow[t]{2}{*}{ OR } & \multicolumn{2}{|c|}{$95 \% \mathrm{CI}$} \\
\hline & $\mathrm{n}$ & $\%$ & $\mathrm{n}$ & $\%$ & & & & lower & upper \\
\hline *010101 & 1 & 1.32 & 1 & 0.53 & ND & 0.494 & 2.493 & 0.154 & 40.38 \\
\hline *030101 & 8 & 10.53 & 15 & 7.98 & 0.442 & 0.506 & 1.357 & 0.550 & 3.347 \\
\hline *040301 & 1 & 1.32 & 2 & 1.06 & ND & 1.000 & 1.240 & 0.111 & 13.881 \\
\hline *040501 & 2 & 2.63 & 9 & 4.79 & 0.206 & 0.650 & 0.538 & 0.113 & 2.548 \\
\hline${ }^{*} 040601$ & 2 & 2.63 & 5 & 2.66 & 0.000 & 1.000 & 0.989 & 0.188 & 5.212 \\
\hline${ }^{*} 070101$ & 2 & 2.63 & 5 & 2.66 & 0.000 & 1.000 & 0.989 & 0.188 & 5.212 \\
\hline *080302 & 3 & 3.95 & 7 & 3.72 & 0.000 & 1.000 & 1.063 & 0.267 & 4.222 \\
\hline *090102 & 10 & 13.16 & 19 & 10.11 & 0.515 & 0.473 & 1.348 & 0.595 & 3.050 \\
\hline${ }^{*} 100101$ & 1 & 1.32 & 5 & 2.66 & 0.043 & 0.836 & 0.488 & 0.056 & 4.248 \\
\hline *110101 & 4 & 5.26 & 14 & 7.45 & 0.406 & 0.524 & 0.690 & 0.220 & 2.169 \\
\hline${ }^{*} 120201$ & 6 & 7.89 & 22 & 11.70 & 0.827 & 0.363 & 0.647 & 0.251 & 1.664 \\
\hline *130201 & 2 & 2.63 & 4 & 2.13 & 0.000 & 1.000 & 1.243 & 0.223 & 6.934 \\
\hline${ }^{*} 140101$ & 7 & 9.21 & 21 & 11.17 & 0.219 & 0.640 & 0.807 & 0.328 & 1.985 \\
\hline *140501 & 8 & 10.53 & 15 & 7.98 & 0.442 & 0.506 & 1.357 & 0.550 & 3.347 \\
\hline * 150101 & 13 & 17.10 & 16 & 8.51 & 4.088 & $0.043^{\mathrm{a}}$ & 2.218 & 1.010 & 4.872 \\
\hline *150201 & 3 & 3.95 & 10 & 5.32 & 0.023 & 0.879 & 0.732 & 0.196 & 2.735 \\
\hline *160201 & 3 & 3.95 & 1 & 0.53 & 2.252 & 0.133 & 7.685 & 0.787 & 75.079 \\
\hline *120101 & 0 & 0 & 3 & 1.60 & ND & 0.559 & ND & ND & ND \\
\hline${ }^{*} 130101$ & 0 & 0 & 2 & 1.06 & ND & 1.000 & ND & ND & ND \\
\hline${ }^{*} 1312$ & 0 & 0 & 2 & 1.06 & ND & 1.000 & ND & ND & ND \\
\hline Others & 0 & 0 & 10 & 0.53 & ND & ND & ND & ND & ND \\
\hline
\end{tabular}

$\mathrm{ND}=$ Not determined. ${ }^{\mathrm{a}} \mathrm{p}^{\prime}=0.043 \times 30=1.290$.

the patients whose renal glomerular number was less than 10 in the renal biopsy sample were excluded from the Haas grade, added up to 23 .

Allele frequencies of the HLA-DRB1 gene in pIgAN patients and healthy subjects in Han Chinese are summarized in table 2. Up to 37 different alleles were detected, of which 30 were found in pIgAN patients while 29 were observed in healthy subjects. The frequencies of HLA-DRB1*140101 and ${ }^{*} 140501$ were significantly increased in the patients compared with healthy subjects (DRB1*140101: OR $=2.263,95 \%$ CI 1.169-4.381, $\mathrm{p}=$ $0.013, \mathrm{p}^{\prime}=0.481 ; D R B 1^{*} 140501: \mathrm{OR}=3.938,95 \% \mathrm{CI}$ $\left.1.675-9.263, \mathrm{p}=0.001, \mathrm{p}^{\prime}=0.037\right)$, while the frequencies of HLA-DRB1*070101, *080203 and ${ }^{*} 160201$ alleles were significantly decreased in patients compared with healthy subjects $\left(D R B 1^{*} 070101\right.$ : OR $=0.205,95 \% \mathrm{CI}$ 0.089-0.473, $\mathrm{p}<0.0005, \mathrm{p}^{\prime}<0.0185 ; D R B 1^{*} 080302$ : $\mathrm{OR}=0.412,95 \%$ CI $0.199-0.851, \mathrm{p}=0.014, \mathrm{p}^{\prime}=0.518$; DRB1*160201: OR $=0.307,95 \%$ CI $0.099-0.952, \mathrm{p}=$ $\left.0.046, \mathrm{p}^{\prime}=1.702\right)$. After adjustment for additional variables, HLA-DRB1*140501 and ${ }^{*} 070101$ were significant- ly different between pIgAN patients and healthy subjects.

The pIgAN patients were divided into different subgroups for further stratification analysis, based on blood pressure (according to the standard of hypertension of WHO-ISH in 1999), 24-hour content of urine protein $(\geq 1$ or $<1 \mathrm{~g} / 24 \mathrm{~h})$, serum IgA level $(>3.45$ or $\leq 3.45$ $\mathrm{mmol} / \mathrm{l}$ ), gross hematuria (positive or negative), renal function (glomerular filtration rate $>60$ or $\leq 60 \mathrm{ml} / \mathrm{min}$ ), and renal histological lesions (evaluated by 2 independent pathologists using the Haas scoring system). Table 3 shows the allele frequencies of the $H L A-D R B 1$ gene in patients with hypertension and in patients with normal blood pressure. The frequency of $H L A-D R B 1^{*} 150101$ was significantly higher in patients with hypertension than in patients with normal blood pressure $(\mathrm{OR}=2.218,95 \% \mathrm{CI}$ $\left.1.010-4.872, \mathrm{p}=0.043, \mathrm{p}^{\prime}=1.290\right)$. Table 4 shows allele frequencies of the HLA-DRB1 gene in patients with normal or abnormal serum IgA level. The frequency of HLA$D R B 1^{*} 090102$ was significantly lower in patients with an abnormal serum IgA level than in patients with a normal 
Table 4. Distribution of $H L A-D R B 1$ alleles in IgAN patients with serum IgA $>3.45$ or $\leq 3.45 \mathrm{mmol} / 1$

\begin{tabular}{|c|c|c|c|c|c|c|c|c|c|}
\hline \multirow[t]{2}{*}{$\begin{array}{l}H L A-D R B 1 \\
\text { allele }\end{array}$} & \multicolumn{2}{|c|}{$\begin{array}{l}\text { Serum } \operatorname{IgA}>3.45 \mathrm{mmol} / \mathrm{l} \\
(\mathrm{n}=35 \times 2)\end{array}$} & \multicolumn{2}{|c|}{$\begin{array}{l}\text { Serum IgA } \leq 3.45 \mathrm{mmol} / \mathrm{l} \\
(\mathrm{n}=97 \times 2)\end{array}$} & \multirow[t]{2}{*}{$x^{2}$} & \multirow[t]{2}{*}{$\mathrm{p}$} & \multirow[t]{2}{*}{ OR } & \multicolumn{2}{|c|}{$95 \% \mathrm{CI}$} \\
\hline & $\mathrm{n}$ & $\%$ & $\mathrm{n}$ & $\%$ & & & & lower & upper \\
\hline *010101 & 1 & 1.43 & 1 & 0.52 & ND & 0.461 & 2.797 & 0.173 & 45.331 \\
\hline${ }^{*} 030101$ & 4 & 5.71 & 19 & 9.79 & 1.076 & 0.300 & 0.558 & 0.186 & 1.702 \\
\hline${ }^{*} 040301$ & 1 & 1.43 & 2 & 1.03 & ND & 1.000 & 1.391 & 0.124 & 15.587 \\
\hline${ }^{*} 040501$ & 2 & 2.86 & 9 & 4.64 & 0.085 & 0.771 & 0.605 & 0.127 & 2.869 \\
\hline${ }^{*} 070101$ & 1 & 1.43 & 6 & 3.09 & 0.095 & 0.757 & 0.454 & 0.054 & 3.840 \\
\hline${ }^{*} 080302$ & 3 & 4.29 & 7 & 3.61 & 0.000 & 1.000 & 1.196 & 0.301 & 4.759 \\
\hline${ }^{*} 090102$ & 3 & 4.29 & 26 & 13.4 & 4.372 & $0.037^{\mathrm{a}}$ & 0.289 & 0.085 & 0.988 \\
\hline${ }^{*} 100101$ & 3 & 4.29 & 3 & 1.55 & 0.723 & 0.395 & 2.851 & 0.562 & 14.467 \\
\hline${ }^{*} 110101$ & 3 & 4.29 & 15 & 7.73 & 0.496 & 0.481 & 0.534 & 0.15 & 1.905 \\
\hline${ }^{*} 120101$ & 2 & 2.86 & 1 & 0.52 & ND & 0.173 & 5.676 & 0.507 & 63.602 \\
\hline${ }^{*} 120201$ & 9 & 12.9 & 19 & 9.79 & 0.237 & 0.626 & 1.359 & 0.584 & 3.163 \\
\hline *130101 & 1 & 1.43 & 1 & 0.52 & ND & 0.461 & 2.797 & 0.173 & 45.331 \\
\hline${ }^{*} 130201$ & 1 & 1.43 & 5 & 2.58 & 0.007 & 0.932 & 0.548 & 0.063 & 4.772 \\
\hline *1312 & 1 & 1.43 & 1 & 0.52 & ND & 0.461 & 2.797 & 0.173 & 45.331 \\
\hline${ }^{*} 140101$ & 5 & 7.14 & 23 & 11.9 & 1.205 & 0.272 & 0.572 & 0.209 & 1.568 \\
\hline${ }^{*} 140501$ & 7 & 10 & 16 & 8.25 & 0.199 & 0.656 & 1.236 & 0.486 & 3.144 \\
\hline *150101 & 11 & 15.7 & 18 & 9.28 & 2.179 & 0.140 & 1.823 & 0.814 & 4.081 \\
\hline *150201 & 6 & 8.57 & 7 & 3.61 & 1.750 & 0.186 & 2.504 & 0.812 & 7.728 \\
\hline *160201 & 2 & 2.86 & 2 & 1.03 & 0.252 & 0.616 & 2.824 & 0.390 & 20.437 \\
\hline *040601 & 0 & 0 & 7 & 3.61 & 1.385 & 0.239 & ND & ND & $\mathrm{ND}$ \\
\hline Others & 4 & ND & 6 & 0.52 & ND & ND & ND & ND & ND \\
\hline
\end{tabular}

$\mathrm{ND}=$ Not determined. ${ }^{\mathrm{a}} \mathrm{p}^{\prime}=0.037 \times 30=1.110$

serum IgA level $(\mathrm{OR}=0.289,95 \%$ CI $0.085-0.988, \mathrm{p}=$ $\left.0.037, \mathrm{p}^{\prime}=0.111\right)$.

Table 5 shows the allele frequencies of the HLA-DRB1 gene between patients with or without gross hematuria. The frequency of $H L A-D R B 1^{*} 120101$ and ${ }^{*} 120201$ in patients with gross hematuria was significantly higher than in patients without gross hematuria $\left(D R B 1^{*} 120101\right.$ : $\mathrm{OR}=6.825,95 \%$ CI 1.473-31.617, $\mathrm{p}=0.021, \mathrm{p}^{\prime}=0.630$; $\left.D R B 1^{*} 120201: \mathrm{p}=0.038, \mathrm{p}^{\prime}=0.114\right)$. The distribution of $H L A-D R B 1$ alleles in patients with normal renal function or renal insufficiency is listed in table 6. The frequencies of $H L A-D R B 1^{*} 030101$ and ${ }^{*} 040601$ in patients with normal renal function were significantly higher than in patients with renal dysfunction $\left(D R B 1^{*} 030101\right.$ : $\mathrm{OR}=5.654$, 95\% CI 2.317-13.794, $\mathrm{p}<0.0005, \mathrm{p}^{\prime}<0.015 ; \mathrm{DRB1} 1^{*} 040601$ : $\mathrm{OR}=8.033,95 \%$ CI 1.520-42.451, $\left.\mathrm{p}=0.012, \mathrm{p}^{\prime}=0.360\right)$. However, there was no significant difference in the frequencies of the $H L A-D R B 1$ gene when the patients were grouped by other variables.

HLA-DR is the most polymorphic locus in humans, in which over $450 H L A-D R B 1$ alleles (http://www.ebi.ac.uk/ imgt/hla) have so far been detected $[27,28]$. To date, 3,628 single nucleotide polymorphisms of the HLA-DRB1 gene have been identified, many of them being non-synonymous (http://www.ncbi.nlm.nih.gov/sites/entrez, access date, 11 February 2008). Based on sequence similarity and serological specificity, most of the HLA-DRB1 alleles can be divided into 13 allelic lineages (denoted ${ }^{*} 01,{ }^{*} 03$, ${ }^{*} 04,{ }^{*} 07,{ }^{*} 08,{ }^{*} 09,{ }^{*} 10,{ }^{*} 11,{ }^{*} 12,{ }^{*} 13,{ }^{*} 14,{ }^{*} 15$ and ${ }^{*} 16$ ) [29]. HLA class II gene polymorphisms have been implicated in the occurrence and disease progression of pIgAN patients [4]. The present study has shown that HLA$D R B 1^{*} 140501$ (belonging to $D R^{*} 14$ ) and HLA$D R B 1^{*} 070101$ (belonging to $D R^{*} 7$ ) alleles are associated with IgAN in Han Chinese. The higher frequency of $D R^{*} 14$ in pIgAN patients suggests that $D R^{*} 14$ might be a susceptible allele, while $D R^{*} 7$ might be resistant alleles, as evidenced by their significantly lower frequencies in pIgAN patients compared with healthy subjects.

In the current study, we found that frequencies of $H L A-D R B 1^{*} 030101$ in patients with normal renal function were significantly higher than in patients with renal 
Table 5. Distribution of $H L A-D R B 1$ alleles in $\operatorname{IgAN}$ patients with or without gross hematuria

\begin{tabular}{|c|c|c|c|c|c|c|c|c|c|}
\hline \multirow[t]{2}{*}{$\begin{array}{l}H L A-D R B 1 \\
\text { allele }\end{array}$} & \multicolumn{2}{|c|}{$\begin{array}{l}\text { Gross hematuria } \\
(\mathrm{n}=23 \times 2)\end{array}$} & \multicolumn{2}{|c|}{$\begin{array}{l}\text { No gross hematuria } \\
(\mathrm{n}=109 \times 2)\end{array}$} & \multirow[t]{2}{*}{$\chi^{2}$} & \multirow[t]{2}{*}{$\mathrm{p}$} & \multirow[t]{2}{*}{ OR } & \multicolumn{2}{|c|}{$95 \% \mathrm{CI}$} \\
\hline & $\mathrm{n}$ & $\%$ & $\mathrm{n}$ & $\%$ & & & & lower & upper \\
\hline${ }^{*} 030101$ & 5 & 10.90 & 18 & 8.26 & 0.080 & 0.777 & 1.355 & 0.476 & 3.858 \\
\hline${ }^{*} 040301$ & 1 & 2.17 & 2 & 0.92 & ND & 0.437 & 2.411 & 0.214 & 27.165 \\
\hline *040501 & 3 & 6.52 & 8 & 3.67 & 0.224 & 0.636 & 1.831 & 0.467 & 7.185 \\
\hline${ }^{*} 040601$ & 3 & 6.52 & 4 & 1.83 & 1.627 & 0.196 & 3.733 & 0.806 & 17.278 \\
\hline${ }^{*} 070101$ & 0 & 0 & 7 & 3.21 & 0.498 & 0.481 & ND & ND & ND \\
\hline${ }^{*} 080302$ & 0 & 0 & 10 & 4.59 & 1.115 & 0.291 & $\mathrm{ND}$ & ND & ND \\
\hline${ }^{*} 090102$ & 5 & 10.90 & 24 & 11.00 & 0.001 & 0.978 & 0.986 & 0.355 & 2.736 \\
\hline${ }^{*} 100101$ & 1 & 2.17 & 5 & 2.29 & 0.000 & 1.000 & 0.947 & 0.108 & 8.299 \\
\hline${ }^{*} 110101$ & 2 & 4.35 & 16 & 7.34 & 0.168 & 0.682 & 0.574 & 0.127 & 2.587 \\
\hline${ }^{*} 120101$ & 4 & 8.70 & 3 & 1.38 & 5.303 & $0.021^{\mathrm{a}}$ & 6.825 & 1.473 & 31.617 \\
\hline *120201 & 0 & 0 & 24 & 11.00 & 4.318 & $0.038^{\mathrm{b}}$ & ND & ND & ND \\
\hline${ }^{*} 130101$ & 1 & 2.17 & 1 & 0.46 & ND & 0.319 & 4.822 & 0.296 & 78.537 \\
\hline${ }^{*} 130201$ & 1 & 2.17 & 5 & 2.29 & 0.000 & 1.000 & 0.947 & 0.113 & 8.299 \\
\hline *140101 & 5 & 10.90 & 23 & 10.60 & 0.000 & 1.000 & 1.034 & 0.371 & 2.879 \\
\hline${ }^{*} 140501$ & 2 & 4.35 & 21 & 9.63 & 0.752 & 0.386 & 0.426 & 0.096 & 1.886 \\
\hline${ }^{*} 150101$ & 6 & 13.00 & 23 & 10.60 & 0.241 & 0.623 & 1.272 & 0.487 & 3.324 \\
\hline *150201 & 3 & 6.52 & 10 & 4.59 & 0.031 & 0.860 & 1.451 & 0.383 & 5.494 \\
\hline *010101 & 0 & 0 & 2 & 0.92 & ND & 1.000 & ND & ND & $\mathrm{ND}$ \\
\hline${ }^{*} 160201$ & 0 & 0 & 4 & 1.83 & ND & 1.000 & ND & ND & ND \\
\hline Others & 4 & ND & 8 & 0.46 & ND & ND & ND & ND & ND \\
\hline
\end{tabular}

$\mathrm{ND}=$ Not determined. ${ }^{\mathrm{a}} \mathrm{p}^{\prime}=0.021 \times 30=0.630 ;{ }^{\mathrm{b}} \mathrm{p}^{\prime}=0.038 \times 30=0.114$

inadequacy, which is different from that found in Japanese patients [10]. The reason for this is unknown, but may be associated with ethnic differences in altered immune responses in IgAN.

In the past 2 decades, the association of HLA-DRB1 alleles and pIgAN has been studied in various ethnic groups [10-14]. In Japanese and French [19] cohorts, there was a strong association between pIgAN and the HLA$D R 4$ gene; a study of Japanese patients found that some haplotypes of the HLA-DRA locus had an important role in the development of pIgAN [30, 31]. Notably, HLA$D R^{*} 12$ was associated with pIgAN in northern Chinese, while $H L A-D R^{*} 4$ was associated with pIgAN in eastern Chinese [14]. However, there was no association between the HLA-DRB1 gene and pIgAN in European Caucasians [8], and there was no association between $H L A-D R$ and pIgAN in Chinese of Hong Kong [17] and Taiwan [18]. In contrast to these results, our study found that the polymorphisms of the HLA-DRB1 gene were significantly associated with pIgAN in Han Chinese. Such a marked discrepancy may be attributed to racial differences in the genetic background of cohorts from different ethnic groups and differential interplay of IgAN susceptibility genes with environmental factors. Since haplotypes are a better predictor than individual genetic mutations for disease susceptibility, further studies are warranted to explore the association of haplotypes of HLA class II genes with IgAN. Newer techniques are presently being developed, such as high-density single nucleotide polymorphism genome-wide scanning, which will hopefully result not only in better screening of individuals at highest risk, but also in novel therapeutic approaches.

The association of $H L A-D R B 1$ alleles with the disease severity when indicated by renal function of IgAN suggests that disease-associated $H L A-D R B 1$ alleles are similar but not identical, and certain allelic variants are preferentially enriched in specific patient populations with defined clinical characteristics. This also suggests a gene dosing effect of HLA-DRB1 alleles. Therefore, polymorphisms in HLA class II genes can be explored as tools to identify high-risk individuals and to dissect the clinical heterogeneity of IgAN.

Our study indicated that several allelic variants of the HLA-DRB1 gene have been associated with IgAN, sup- 
Table 6. Distribution of $H L A-D R B 1$ alleles in IgAN patients with GFR $\leq 60$ or $>60 \mathrm{ml} / \mathrm{min}$

\begin{tabular}{|c|c|c|c|c|c|c|c|c|c|}
\hline \multirow[t]{2}{*}{$\begin{array}{l}H L A-D R B 1 \\
\text { allele }\end{array}$} & \multicolumn{2}{|c|}{$\begin{array}{l}\mathrm{GFR} \leq 60 \mathrm{ml} / \mathrm{min} \\
(\mathrm{n}=33 \times 2)\end{array}$} & \multicolumn{2}{|c|}{$\begin{array}{l}\mathrm{GFR}>60 \mathrm{ml} / \mathrm{min} \\
(\mathrm{n}=99 \times 2)\end{array}$} & \multirow[t]{2}{*}{$\chi^{2}$} & \multirow[t]{2}{*}{$\mathrm{p}$} & \multirow[t]{2}{*}{ OR } & \multicolumn{2}{|c|}{$95 \% \mathrm{CI}$} \\
\hline & $\mathrm{n}$ & $\%$ & $\mathrm{n}$ & $\%$ & & & & lower & upper \\
\hline${ }^{*} 010101$ & 1 & 1.52 & 1 & 0.51 & $\mathrm{ND}$ & 0.438 & 3.031 & 0.187 & 49.145 \\
\hline${ }^{*} 030101$ & 14 & 21.21 & 9 & 4.55 & 17.289 & $0.000^{\mathrm{a}}$ & 5.654 & 2.317 & 13.794 \\
\hline${ }^{*} 040301$ & 0 & 0 & 3 & 1.52 & ND & 0.575 & ND & ND & ND \\
\hline *040501 & 3 & 4.55 & 8 & 4.04 & 0.000 & 1.000 & 1.131 & 0.291 & 4.394 \\
\hline *040601 & 5 & 7.58 & 2 & 1.01 & 5.919 & $0.015^{\mathrm{b}}$ & 8.033 & 1.520 & 42.451 \\
\hline${ }^{*} 070101$ & 1 & 1.52 & 6 & 3.03 & 0.049 & 0.825 & 0.492 & 0.058 & 4.166 \\
\hline *080302 & 0 & 0 & 10 & 5.05 & 2.217 & 0.136 & ND & ND & ND \\
\hline${ }^{*} 090102$ & 5 & 7.58 & 24 & 12.10 & 1.046 & 0.306 & 0.594 & 0.217 & 1.626 \\
\hline${ }^{*} 100101$ & 2 & 3.03 & 4 & 2.02 & 0.000 & 1.000 & 1.516 & 0.271 & 8.470 \\
\hline *110101 & 7 & 10.61 & 11 & 5.56 & 1.272 & 0.259 & 2.017 & 0.748 & 5.438 \\
\hline${ }^{*} 120101$ & 0 & 0 & 3 & 1.52 & ND & 0.575 & $\mathrm{ND}$ & $\mathrm{ND}$ & ND \\
\hline${ }^{*} 120201$ & 5 & 7.58 & 23 & 11.60 & 0.852 & 0.356 & 0.624 & 0.227 & 1.712 \\
\hline${ }^{*} 130101$ & 0 & 0 & 2 & 1.01 & ND & 1.000 & ND & ND & ND \\
\hline *130201 & 1 & 1.52 & 5 & 2.53 & 0.227 & 1.000 & 0.594 & 0.068 & 5.177 \\
\hline${ }^{*} 1312$ & 0 & 0 & 2 & 1.01 & ND & 1.000 & ND & ND & ND \\
\hline${ }^{*} 140101$ & 5 & 7.58 & 23 & 11.60 & 0.852 & 0.356 & 0.624 & 0.227 & 1.712 \\
\hline *140501 & 6 & 9.09 & 17 & 8.59 & 0.000 & 1.000 & 1.065 & 0.401 & 2.824 \\
\hline *150101 & 9 & 13.64 & 20 & 10.10 & 0.633 & 0.426 & 1.405 & 0.606 & 3.260 \\
\hline *150201 & 0 & 0 & 13 & 6.57 & 3.263 & 0.071 & ND & ND & ND \\
\hline *160201 & 0 & 0 & 4 & 2.02 & ND & 0.575 & ND & ND & ND \\
\hline Others & 2 & 0 & 8 & 0.51 & ND & ND & ND & ND & ND \\
\hline
\end{tabular}

GFR $=$ Glomerular filtration rate; $\mathrm{ND}=$ not determined.

${ }^{\mathrm{a}} \mathrm{p}^{\prime}<0.0005 \times 30=0.015 ;{ }^{\mathrm{b}} \mathrm{p}^{\prime}=0.015 \times 30=0.45$.

porting a role for $\mathrm{T}$ cell receptor-HLA antigen interactions in the pathologic process of IgAN. It is unclear how HLA-DRB1 polymorphisms contribute to the pathogenesis of IgAN. Since HLA-DRB1 plays a critical role in presenting antigens to $T$ lymphocytes, we speculate that the polymorphisms of the $H L A-D R B 1$ gene would alter its function and thus result in abnormal immune responses including increased serum IgA levels and IgA deposit in the glomerulus.

IgA usually helps the body to fight infections and toxins encountered in the gut and the lungs, but it is still not understood why IgA is deposited in the kidneys. A number of immunosuppressant drugs have been tested on their own and in combination, but there is little evidence of definite benefit for IgAN so far.

In conclusion, our study indicates that polymorphisms of the HLA-DRB1 gene may be a useful marker associated with the susceptibility of pIgAN in Han Chinese, and HLA-DRB1*140501 might be a susceptible allele, while HLA-DRB1*070101 might be resistant alleles. Studies are warranted to explore the immunological mechanisms for the genotype-disease phenotype association. Further family-based studies are needed to test whether these genetic risk markers confer an effect or whether it is due to other variants nearby with which they are in linkage disequilibrium (e.g., haplotypes).

References Engl J Med 2002;347:738-748.

2 Hsu SI, Ramirez SB, Winn MP, Bonventre JV, Owen WF: Evidence for genetic factors in the development and progression of IgA nephropathy. Kidney Int 2000;57:1818-1835.

3 Schmidt S, Ritz E: Genetic factors in IgA nephropathy. Ann Med Interne (Paris) 1999; 150:86-90.

-4 Beerman I, Novak J, Wyatt RJ, Julian BA, Gharavi AG: The genetics of IgA nephropathy. Nat Clin Pract Nephrol 2007;3:325338.

5 Maxwell PH, Wang Y: Genetic studies of IgA nephropathy. Nephron Exp Nephrol 2006; 102:e76-e80. 
6 Horton R, Wilming L, Rand V, Lovering RC, Bruford EA, Khodiyar VK, Lush MJ, Povey S, Talbot CC Jr, Wright MW, Wain HM, Trowsdale J, Ziegler A, Beck S: Gene map of the extended human MHC. Nat Rev Genet 2004;5:889-899.

$\checkmark 7$ Floege J, Feehally J: IgA nephropathy: recent developments. J Am Soc Nephrol 2000;11: 2395-2403.

$>8$ Moore R: MHC gene polymorphism in primary IgA nephropathy. Kidney Int Suppl 1993;39:S9-S12.

-9 Tolkoff-Rubin NE, Cosimi AB, Fuller T, Rublin RH, Colvin RB: IgA nephropathy in HLA-identical siblings. Transplantation 1978;26:430-433.

10 Hiki Y, Kobayashi Y, Tateno S, Sada M, Kashiwagi N: Strong association of HLADR4 with benign IgA nephropathy. Nephron 1982;32:222-226.

-11 Kashiwabara H, Shishido H, Tomura S, Tuchida H, Miyajima T: Strong association between IgA nephropathy and HLA-DR4 antigen. Kidney Int 1982;22:377-382.

12 Kasahara M, Hamada K, Okuyama T, Ishikawa N, Ogasawara K, Ikeda H, Takenouchi T, Wakisaka A, Aizawa M, Kataoka Y, Miyamoto R, Kohara M, Naito S, Kashiwagi N, Hiki Y: Role of HLA in IgA nephropathy. Clin Immunol Immunopathol 1982;25:189195.

13 Hiki Y, Kobayashi Y, Ookubo M, Kashiwagi $\mathrm{N}$ : The role of HLA-DR4 in the long-term prognosis of IgA nephropathy. Nephron 1990;54:264-265.

14 Chen N, Fan LA, Yang YR, Qian P, Gu Z, Dong JZ: The association between HLA and IgA nephropathy and its clinical implication. Chin J Immunol 1996;12:85-88.
5 Raguenes O, Mercier B, Cledes J, Whebe B, Ferec C: HLA class II typing and idiopathic IgA nephropathy (IgAN): Dqb1*0301, a possible marker of unfavorable outcome. Tissue Antigens 1995;45:246-249.

16 Chen XM, Bo LQ, Chen Q: HLA-DR alleles' frequencies in IgA nephropathy using sequence specific oligonucleotide and its clinical implication. Chin Med J 1992;72:206209.

17 Li PK, Poon AS, Hawkins BR, Yeung VT, Bo $\mathrm{YH}$, Lai KN: Restriction fragment length polymorphism of HLA-DQ and -DR allogenotypes in normal southern Chinese. Tissue Antigens 1993;42:502-508.

18 Huang CC, Hu SA, Lin JL, Wu JH: HLA and Chinese IgA nephropathy in Taiwan. Tissue Antigens 1989;33:45-47.

19 Fauchet R, Le Pogamp P, Genetet B, Chevet D, Gueguen M, Simon P, Ramee MP, Cartier F: HLA-DR4 antigen and IgA nephropathy. Tissue Antigens 1980;16:405-410.

20 Scolari F, Amoroso A, Savoldi S, Mazzola G, Prati E, Valzorio B, Viola BF, Nicola B, Movilli E, Sandrini M, Campanini M, Maiorca R: Familial clustering of IgA nephropathy: further evidence in an Italian population. Am J Kidney Dis 1999;33:857-865.

21 Churg J, Bernstein J, Glassock RJ: WHO Monograph. Renal Disease Classification and Atlas of Glomerular Disease, ed 4. New York, Ikagu Shoin Medical Publishers Inc, 1995.

22 Haas M: Histology and immunohistology of IgA nephropathy. J Nephrol 2005;18:676680.

23 Kotsch K, Wehling J, Blasczyk R: Sequencing of HLA class II genes based on the conserved diversity of the non-coding regions: sequencing based typing of HLA-DRB genes. Tissue Antigens 1999;53:486-497.
24 Lancaster A, Nelson MP, Meyer D, Thomson G, Single RM: PyPop: a software framework for population genomics: analyzing largescale multi-locus genotype data. Pac Symp Biocomput 2003:514-525.

25 Woolf B: On estimating the relation between blood group and disease. Ann Hum Genet 1955;19:251.

26 Svejgaard A, Ryder LP: HLA and disease associations: detecting the strongest association. Tissue Antigens 1994;43:18-27.

27 Robinson J, Waller MJ, Parham P, de Groot N, Bontrop R, Kennedy LJ, Stoehr P, Marsh SG: IMGT/HLA and IMGT/MHC: sequence databases for the study of the major histocompatibility complex. Nucleic Acids Res 2003;31:311-314.

28 Marsh SG: Nomenclature for factors of the HLA system, update July 2007. Tissue Antigens 2007;70:445-447.

29 von Salome J, Gyllensten U, Bergstrom TF: Full-length sequence analysis of the HLADRB1 locus suggests a recent origin of alleles. Immunogenetics 2007;59:261-271.

30 Akiyama F, Tanaka T, Yamada R, Ohnishi Y, Tsunoda T, Maeda S, Takei T, Obara W, Ito K, Honda K, Uchida K, Tsuchiya K, Nitta K, Yumura W, Nihei H, Ujiie T, Nagane Y, Miyano S, Suzuki Y, Fujioka T, Narita I, Gejyo F, Nakamura Y: Single-nucleotide polymorphisms in the class II region of the major histocompatibility complex in Japanese patients with immunoglobulin A nephropathy. J Hum Genet 2002;47:532-538.

31 Ogahara S, Naito S, Abe K, Michinaga I, Arakawa K: Analysis of HLA class II genes in Japanese patients with idiopathic membranous glomerulonephritis. Kidney Int 1992; 41:175-182. 